Winter 2008

\title{
Securing the Global City: Crime, Consulting, Risk, and Ratings in the Production of Urban Space
}

\author{
Katharyne Mitchell \\ University of Washington \\ Katherine Beckett \\ University of Washington
}

Follow this and additional works at: https://www.repository.law.indiana.edu/ijgls

Part of the Civil Law Commons, Criminal Law Commons, and the International Law Commons

\section{Recommended Citation}

Mitchell, Katharyne and Beckett, Katherine (2008) "Securing the Global City: Crime, Consulting, Risk, and Ratings in the Production of Urban Space," Indiana Journal of Global Legal Studies: Vol. 15 : Iss. 1 , Article 5 .

Available at: https://www.repository.law.indiana.edu/ijgls/vol15/iss1/5

This Symposium is brought to you for free and open access by the Law School Journals at Digital Repository @ Maurer Law. It has been accepted for inclusion in Indiana Journal of Global Legal Studies by an authorized editor of Digital Repository @ Maurer Law. For more information, please contact rvaughan@indiana.edu.

JEROME HALL LAW LIBRARY

INDIANA UNIVERSITY Maurer School of Law
Bloomington 


\title{
Securing the Global City: Crime, Consulting, Risk, and Ratings in the Production of Urban Space
}

\author{
Katharyne Mitchell* \& Katherine Beckett**
}

\begin{abstract}
The last decade has witnessed the rise of private transnational institutions that increasingly influence the organization and management of urban space. Two institutions are especially powerful in this regard: bond-rating agencies and global security firms. Bolstered by a discourse of risk and the need to securitize cities, these institutions have garnered enormous amounts of power with respect to urban social and spatial control. They are implicated in the imprisonment and displacement of marginalized populations, the intensification of gentrification, and general shifts in municipal funding priorities. The authors illustrate these themes through a case study of New York City, followed by an example of the transnational movement of these forces and their exportation to sites such as Mexico City.
\end{abstract}

\section{INTRODUCTION}

Contemporary globalization is often described as a process involving heightened interdependencies between different regions of the world, as well as a growing transnational movement of capital, people, and goods. Over the past few decades, a number of institutions arose to enable and facilitate these movements and to aid in the global expansion of free-market ideas and practices. These transnational institutions can be broadly characterized as "neoliberal" as a result of their promulgation of market-based strategies for managing this movement and for controlling the places and populations implicated in these new cross-border relationships.

* Professor of Geography and the Simpson Professor in the Public Humanities, University of Washington.

** Associate Professor in the Department of Sociology and the Law, Societies, and Justice Program, University of Washington. 
In this paper we examine two such institutions: bond-rating agencies and the global security industry. Beginning with a case study of an American city that was profoundly disciplined and regulated in the 1970s, and again in the 1990s, we show how these disciplinary processes transmigrated more recently to Mexico, specifically with respect to the management of the urban spaces and populations of Mexico City. Examining the impact of these institutions and ideas across borders illuminates two dynamics: (1) the policies and practices through which American interests and priorities are exported around the globe and (2) the multiple ways that neoliberalism is disseminated as an ideology of effective and neutral governance through its active spatial extension and entrenchment.

Neoliberalism is generally understood as involving both market liberalization and some degree of authoritarian control.' States are narrated as active, often coercive forces in these processes, both through withdrawing the social provisions of an earlier, Keynesian or "welfarist" moment, as well as through the vigorous creation of new conditions of privatization and deregulation through which markets expand. ${ }^{2}$ What is less commonly studied is the manner in which private transnational institutions are now usurping or co-producing many of these former state-based functions of marketization and coercion. These private institutions and public-private partnerships effectively undermine democratic autonomy at the same time that they facilitate and entrench neoliberal market expansion and population control. In what follows, we briefly describe the rise of these two U.S.-dominated transnational industries. The second section examines how these institutions affected, and in the case of the transnational crime consulting industry, emerged from, developments in New York City. The final section explores the subsequent exportation of these institutional practices and orthodoxies to Mexico, and suggests that the implications of this shift in power for cities worldwide are enormous, especially with respect to municipal autonomy, democratic representation, and the welfare of marginalized urban populations.

\section{Risk and Ratings, Crime and Consulting: The Rise of Two Key Transnational Institutions}

Bonds are contracts in which an investor agrees to lend money and a borrower agrees to return that money in specified amounts at a scheduled time. Bond-rating agencies rate the ability and willingness of the borrower to follow the

1. See David Harvey, A Brief History of Neoliberalism (2005).

2. See Jamie Peck \& Adam Tickell, Neoliberalizing Space, 34 Antıpode 380 (2002). 
terms of that contract. ${ }^{3}$ While public or "sovereign" bonds have been used as methods of raising money for centuries, only since the early twentieth century have corporate bonds, and subsequently municipal bonds, become significant components of the bond market.

Corporate bonds originated to help finance the expansion of the U.S. railroads; they are commonly depicted as an "American financial innovation" that did not operate internationally on a large scale until the 1970s. Moody's, the first bond-rating agency, was a U.S. firm started to provide information to lenders interested in investing in these railroad bonds. This U.S. dominance has continued into the present, with the three largest agencies headquartered in New York City, and hundreds of offices now operating overseas. ${ }^{5}$

The tremendous growth of bond-rating companies over the past three decades is the direct result of globalization and financial liberalization. ${ }^{6}$ With the collapse of Bretton Woods in 1971 and the renewal of floating exchange rates, capital moved more freely and rapidly across international borders. ${ }^{7}$ At the same time, the disintermediation of banks meant that capital markets loaned money directly to borrowers, including bond issuers. ${ }^{8}$ With banks absorbing less of the risk associated with lending, the assessments of risk made by bond-rating agencies grew in importance, and these companies expanded tremendously in power and prestige over the next three decades. ${ }^{9}$

Concern about the risks associated with transnational credit markets have become tied to greater demands for global security, both of financial instruments

3. E.g., Richard Sylla, A Historical Primer on the Business of Credit Rating, in Ratings, Ratinc Agencies and the Global Finangial System 19, 21 (Richard Levich et al. eds., 2002).

4. Id. at 22.

5. The two largest agencies are Moody's Investor Services, and Standard \& Poor's. Fitch, at third place, is owned by the French company FIMALAC, and has dual headquarters in New York and London. Regulatory structures imposed since the 1970s have favored the older and larger bond-ratings firms over newer entries, leading to a near monopoly by the big three. See Lawrence J. White, The Credit Rating Industry: An Industrial Organization Analysis, in Ratings, Rating Agencies and the Global Financial System, supra note 3, at 41, 45-46.

6. See Timothy Sinclair, The New Masters of Capital: American Bond Rating Agencies and the Politics of Creditworthiness (2005).

7. Peter Dicken, Global Shift: Reshaping the Global Economic Shift in the 2ist CenTuRY (4th ed. 2003).

8. See Sinclair, supra note 6.

9. As of 2000 , Moody's coverage reached $\$ 30$ trillion in debt issuances (ratings and analysis), and $S \& P$ was in excess of $\$ 11$ trillion in debt issuances. Moody's had 15,000 structured transactions, maintained 4,200 corporate relationships, and operated in more than 100 countries. See White, supra note 5 , at 45. 
and physical environments. Bond-rating agencies seem to provide this financial security for lenders, who desire precise, detailed, highly graded computations of risk in making their own calculations. In investigating municipal credit worthiness, the agencies base their ratings on financial and management history, and the economic outlook of the city. Despite the highly subjective quality of many judgments, the agencies promote a sense of neutrality and rationality in making these assessments. This imparts a weightiness and gravitas to the assessments that make them difficult to dispute. These assessments have had particularly strong ramifications in the areas of municipal bond issuances and ratings. ${ }^{10}$

According to Jason Hackworth, the ratings agencies have become especially influential for urban development and socioeconomic organization because of three intertwined forces. ${ }^{11}$ First, general disinvestment in cities by the federal government has forced city governments and public authorities to borrow more (by issuing bonds) in order to provide the same basic services that were formerly covered by federal dollars. The second force comes from the increased investment of pension funds, money market funds, and other institutions in diversified financial portfolios. Laws that limit the amounts of speculative grade (or high-risk) debt that these types of institutions can hold have made the ratings of bonds increasingly important. "Given the increased presence of funds with such limitations, the judgments of rating agencies have ipso facto become more important because there are fewer bond buyers willing and legally able to ignore their assessments." 12 Finally, banks today lend at far lower rates than previously, and many capital market lenders now absorb risk directly. This has led to an increased desire for professional assessments in order to reduce the perceived riskiness of direct (nonintermediated) loans.

In assessing risk, both the lenders and the agencies look for strong fiscal discipline as a primary criterion of a secure, low-risk investment option. This demand for fiscal discipline in the financial markets has been accompanied by increased regulation and surveillance by government, and also by private consortiums such as banks, regulatory agencies, and conservative think tanks. ${ }^{13} \mathrm{New}$ apparatuses of private and public-private surveillance and regulation have also

10. See Sinclair, supra note 6.

11. See Jason Hackworth, The Neoliberal City: Governance, Ideology, and Development in American Urbanism (2007).

12. Id. at 24 .

13. Sinclair, supra note 6, at 1-15. For example, the Bank for International Settlements (BIS), the American Enterprise Institute, and the bond-rating agencies themselves have all increased their regulation and surveillance. 
emerged in the risk-reduction management of physical environments such as urban spaces and infrastructure. As a result, the work of bond-rating agencies often reinforces the perceived need to hire some of America's "top cops" to help local authorities impose order and discipline on urban residents; the financial security of a city was dependent on its physical security.

\section{The Global Security Industry}

Consulting firms are an important part of the multibillion dollar transnational security industry. These firms offer consulting services to private and public entities seeking to enhance their security on issues ranging from geological threats to terrorism. The industry received a significant boost after $9 / 11$, because "a growing crop of security consultants has sprung up to help major corporations increase their defenses."14 Worldwide, private spending on security is estimated to be greater than $\$ 50$ billion. . $^{15}$

A small but expanding subset of this industry offers consulting services primarily to federal, state, and local governments seeking to reduce crime and disorder. While many of the security consulting firms identify corporations as their target market, firms such as Giuliani Partners and The Bratton Group L.L.C. also seek to influence regional and municipal policing practices and crime policies. Although these consulting groups comprise a small portion of the growing transnational security sector, their focus on public policy-and the fact that they are often funded by wealthy business leaders and groups - raises important questions about democratic governance. ${ }^{16}$

The fact that several of the most prominent of these firms so aggressively promote the "New York model" is also controversial. The New York model is the approach to crime and disorder taken in New York City under Mayor Giuliani based on a particular interpretation of "broken windows policing." This model justified an especially aggressive law enforcement approach to a number of urban social problems. It is this law enforcement approach that has been exported by leading transnational security consulting firms. In particular, former New York

14. Paul Magnusson \& Spencer E. Ante, The Booming Security Business: Anti-Terrorism Consultants are Cleaning up as Companies Everywhere Boost Spending, Bus. WK., July 25, 2005, at 30.

15. Id.

16. As Bratton said in reference to his consulting arrangement with the city of Caracas, Venezuela, "What is unique about this is the embracing of the initiative by the private sector; that's truly a watershed moment in Venezuela and maybe in Latin America." Andy Webb-Vidal, New York Supercop Takes a Crack at Caracas, Fin. Times, March 22, 2001, at 3. 
Police Chief William J. Bratton's consulting group, The Bratton Group, L.L.C., and Giuliani Partners have offered their expertise regarding crime and security to public officials in Mexico and South America.

The work of these and other transnational security consulting firms has coincided with a push by the conservative think tank, the Manhattan Institure, to "share ideas for urban renewal with leaders in Latin America." ${ }^{\prime 7}$ The Manhattan Institute provided the intellectual rationale for Giuliani's revolution and now has a new office in Santiago, Chile. In addition, the think tank recently began the Inter-American Policy Exchange, a new initiative to promote zero tolerance policing, educational reform (i.e. vouchers), and pro-business tax reform in Latin American cities. ${ }^{18}$ As one New York Times journalist put it, "At times it seems that Latin American leaders cannot get enough of the Institute and its ideas." 19 The Institute's ideas were, it purports, tested and proven successful under the leadership of Rudolph (Rudy) W. Giuliani in New York City. Indeed, the New York model revealed the importance of bond-rating institutions and laid the foundation for a portion of the transnational security consulting sector. The next section explicates the New York City experience in greater detail.

\section{A. Bonds, Politics, and Security in New York City}

New York City's financial woes of the 1970s were not unique. The city experienced problems that were plaguing many older northeast cities in the United States during this time, including the loss of its manufacturing base, demographic shifts, and a major federal disinvestment in economic and social programs. ${ }^{20}$ Earlier waves of suburbanization in the post-war period, encouraged by development subsidies in the form of highway construction and tax breaks, spurred the movement of primarily white, middle-class city-dwellers to the new suburbs ringing the city. ${ }^{21}$ This "white flight" left a population behind that was dependent on the

17. Manhattan Institute for Policy Research, President's Welcome, http://www.manhattaninstitute.org/html/iape.htm (last visited June 9, 2007).

18. See Anthony DePalma, The Americas Court a Group that Changed New York, N.Y. Times, Nov. 11, 2002, available at http://www.manhattan-institute.org/html/_nyt-the_americas.htm.

19. Id.

20. See William K. Tabb, The Long Default: New York City and the Urban Fiscal Crisis (1982).

21. See Richard A. Walker, A Theory of Suburbanization: Capitalism and the Construction of Urban Space in the United States, in Urbanization and Urban Planning in Capitalist Society 383 (1981). 
fast-disappearing light manufacturing jobs in the city, and also on the social services provided to recent immigrants and others relying on cheap and efficient transportation, affordable housing, and free education. ${ }^{22}$

The economic and demographic restructuring of this period led to reduced taxes for city coffers at the same time that the federal government was reducing its involvement in service provisioning. ${ }^{23}$ The combination of these factors increased municipal debt and the necessity of borrowing more money through banks and the issuance of municipal bonds. ${ }^{24}$ Numerous local banks were involved in this process as both lenders and underwriters of bonds, and made a significant profit through much of the early 1970s, especially as the city's financial problems became increasingly public and interest rates began to soar..$^{25}$ In contrast, the city went further and further into debt as its service expenses rose. Between 1974 and 1975 alone these expenses jumped nearly 3 percent. ${ }^{26}$

The issuance and rating of bonds played an increasingly important role during this time period. With the municipal deficit growing on a yearly basis, the impending financial crisis was staved off temporarily through the issuance of more and more short-term bonds ("notes") to cover the longer-term debt. This "long default" stretched on for several painful months between 1974 and 1975, and provided the opening for the financial community to take stronger control over city resources and fiscal allocations, including through the formation of the Financial Community Liaison Group (FCLG) in January 1975. "The overt function of the FCLG was to establish a formal mechanism through which the financial community and the city could cooperatively work to reopen the municipal

22. Manufacturing employment peaked at 1,073,000 workers in 1947. Between 1950 and 1980 , manufacturing jobs in New York City declined from 30 percent of payroll employment to 15 percent, a loss of hundreds of thousands of jobs. See $\mathrm{T}_{\mathbf{A B B}}$, supra note 20 , at 75 . The decline of light manufacturing and the conversion of thousands of manufacturing lofts to residences during this time were encouraged by municipal zoning changes and tax abatements for developers. See SHAron Zukin, Loft Living: Culture and Capital in Urban Change (1982).

23. See, e.g., Harvey, supra note 1, at 44-48 (discussing the New York City crime crisis as a key moment in the repudiation of the former Keynesian principals of demand-side intervention and regulation and the beginning of the neoliberal, market-oriented era).

24. See Martin Shefter, Political Crisis/Fiscal Crisis: The Collapse and Revival of New York City 108 (1992).

25. See Eric Lichten, Class, Power and Austerity: The New York City Fiscal Crisis (1986); see also SHEFTER, supra note 24, at 108 (arguing that the "healthy fees and commissions they earned for their services" made New York's commercial banks loathe to ask many questions about the city's financial practices).

26. SHEFTER, supra note 24, at 104. 
credit markets to the city. Essentially, however, this committee sought to establish the power of finance capital over the city's fiscal affairs." ${ }^{27}$

Following the establishment of the FCLG, a municipal bond analyst for Weeden and Company outlined the city's fiscal problems and suggested a number of solutions. These included the mass firings of municipal employees, the takeover of the city's fiscal affairs by financial managers, and a structural reorganization of the city similar to those done in bankruptcy proceedings. ${ }^{28}$ The formation of the FCLG and these suggestions were just the first of a series of changes that became more austere and coercive as the crisis deepened over the course of the year.

One of the events precipitating the worst moments of the crisis was the downgrading of the city's bonds. In April 1975, Standard and Poor's (S\&P) suspended its bond-ratings, and in October 1975, Moody's downgraded the city twice, from $\mathrm{A}$ to $\mathrm{Ba}$ to $\mathrm{Caa}^{29}$ The second move propelled municipal bonds into speculative grade status, essentially making them unmarketable and instantly bankrupting the city. From this point on, the city lost almost all control over the allocation of its resources and future planning options. The new agencies that were brought in to help restructure municipal finances and general spending priorities earlier in the year were essentially given carte blanche in their municipal rescue. ${ }^{30}$ Thus the changing bond market and bond-ratings were key to the ensuing loss of autonomy for the city. As stated by the conservative think tank, The American Enterprise Institute, "Although it is difficult to pinpoint the time when the financial problems facing New York City stopped being problems and started being a crisis, one may safely assume that the crisis had been reached early in 1975 when the city's bonds and notes could not be sold at any reasonable price."'31

Following the near fiscal default of New York City in 1975, and the financial crises in Latin America and Asia in the 80s and 90s, the demand for fiscal discipline became increasingly vociferous. For many cities around the world, this led to the elimination or vast reduction of social services at the same time that it locked in multiple forms of market-based neoliberal reforms. ${ }^{32}$

A new set of non-local institutions emerged to help restructure New York

27. Lichten, supra note 25 , at 108 .

28. Id.

29. See Sinclair, supra note 6 , at 113 ; Hack worth, supra note 11 , at 34.

30. It should be noted that the mayor and comptroller unsuccessfully requested federal relief at

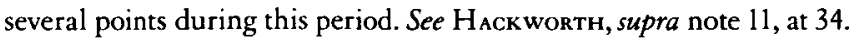

31. Attiat F. Ott \& Jang H. Yoo, New York City's Financial Crisis: Can The Trend Be ReVERSED? 2 (1975).

32. See, e.g., Contesting Neoliberalism: Urban Frontiers (Helga Leitner, et al. eds., 2007). 
City's finances and labor policies. These included the Municipal Assistance Corporation (MAC), the Emergency Financial Control Board (EFCB), the Office of the Special Deputy Comptroller for New York City (OSDC), and the Office of New York City Finance in the U.S. Treasury Department. ${ }^{33}$ The MAC was authorized to sell bonds for the city and both the MAC and the EFCB were run by members of the financial elite. Of the nine members of the MAC board, for example, eight had banking and brokerage connections. One of the main architects of the city's "rescue" involved in both of these agencies was Felix Rohatyn, a partner at the investment banking firm, Lazard Freres, and a director of ITT and six other large corporations. Rohatyn designed many of the fiscal reform measures prescribed for the city, and organized a three-year austerity plan involving major cuts to the work force and to social services. This transition in governing power has been referred to as a bankers' coup..$^{34}$

The loss of democratic control over the city had numerous ramifications, but none were as important as the changes in municipal spending priorities. The MAC architects shifted funding away from sites of collective consumption and towards business-friendly ventures in the areas of real estate, producer services, banking, and insurance..$^{35}$ Elements of previous urban policy that came under attack included City University of New York's (CUNY) policy of tuition-free education, the city's subsidized housing, rent control, transportation subsidies, and health facilities, especially with respect to welfare. ${ }^{36}$ Other targeted areas included the unionized municipal work force.

The conservative reasoning of the austerity program articulated the causes of the city's "fiscal ill health," as primarily attributed to unionized labor, the poor, and immigrants. ${ }^{37}$ Certainly, the greatest impact of the austerity measures was felt by these groups:

Between January 1, 1975, and May 31, 1976, the city payroll was cut by 15 percent, or 47,412 employees. Park and playground payrolls were cut by 25 percent, the sanitation department by close to that, and schools by slightly more.... The austerity program, as one might have predicted, had a much greater impact on blacks and Puerto Ri-

33. See Shefter, supra note 24, at 133.

34. Jack Newfield \& Paul Du Brul, The Abuse Of Power: The Permanent Government And The Fall Of New York (1977).

35. See Robert Fitch, The Assassination Of New York (1993).

36. See Shefter, supra note 24, at 147.

37. See, e.g., OTr \& Yoo, supra note 31 , at 16. 
cans than on other New Yorkers. In 1975, 15,000 teachers and paraprofessionals--constituting 20 percent of union membership-were laid off, and this reduced the proportion of black and Spanish-surnamed teachers from 11 to 3 percent-remember that two-thirds of the students are black or Spanish surnamed.... Between the fall of 1974 and the winter of 1976, the city workforce lost half its Spanishsurnamed workers, two-fifths of its black male employees, and onethird of its female employees. ${ }^{38}$

The impact of the MAC plans were felt positively by the business community, which experienced a resurgence in the late 1970s and 1980s in areas such as real estate, banking, and insurance. ${ }^{39}$ For example, manufacturing lofts were converted into residential lofts in Manhattan throughout the 1970s. While a number of new zoning resolutions, building codes, and tax incentives enabled this conversion process, the most important by far was the 1975 revision of the J-51 program to provide tax benefits for large-scale residential conversion. This was closely followed by a 1976 zoning act that created TriBeCa and legalized residential conversion in this area. ${ }^{40}$

The new development opportunities afforded by the MAC restructuring were not just experienced in loft conversion but also in other forms of gentrification that took place throughout the following decade. ${ }^{41}$ In Battery Park City, Times Square, the Upper West Side, and South Street Seaport, among other hot spots, massive real estate developments became emblematic of the new priorities of the MAC and the EFCB managers following the city's earlier fiscal crisis. ${ }^{42}$ In addition to local and federal changes, global financial restructuring during this time also greatly facilitated the city's widespread gentrification as new forms of "securitization" enabled real estate financing to connect to broader, non-local capital markets, leading to what many have termed the first era of the "globalization of real estate." ${ }^{\text {3 }}$

38. See $\mathrm{T}_{\mathrm{ABB}}$, supra note 20 , at 30 .

39. See Firch, supra note 35.

40. See Zukin, supra note 22, at 52.

41. See, e.g., Neil Smith, The New Urban Frontier: Gentrification and The Revanchist City (1996); Janet A bu-Lughod, From Urban Village to East Village: Battle for New York's Lower East Side (Janet L. Abu-Lughod ed., 1994).

42. See M. Christine Boyer, The City of Illusion: New York's Public Places, in The Restless Urban Landscape II (Paul L. Knox ed., 1993).

43. E.g., John Logan, Cycles and Trends in the Globalization of Real Estate, in The Restless URBAN LANDSCAPE, supra note 42, at 33-39. 
The general financial boom and widespread gentrification of the 1980s was accompanied by increasing social polarization in the city and rising homelessness, among other social ills. ${ }^{44}$ The manifestation of these problems on the city streets became more pronounced following the recession of the early 1990s and provided the rationale for the incoming mayor, Rudy Giuliani, to introduce a harsh new "zero tolerance" to urban "disorder," including homelessness. ${ }^{45}$

Rudy Giuliani was elected mayor of New York City in 1993 and again in 1997. Throughout his campaign and tenure in office, Giuliani stressed the capacity of municipal leadership to bring about significant change: “Time brings all things to pass, and with the start of my Administration New York City is poised for dramatic change. The era of fear has had a long enough reign. The period of doubt has run its course." ${ }^{.46}$ Under his regime, neoliberal policies of privatization, cuts to social services, and new work rules intended to increase productivity were implemented alongside increased policing, anti-homeless laws, and the harassment of marginal populations. In particular, Giuliani sought to reduce taxes, trim government and government expenditures (mainly through the privatization of public resources), and decrease welfare benefits and caseloads. At the same time that he stressed the need to cut back government employment and expenditures, he repeatedly emphasized the need to reduce crime through aggressive law enforcement efforts. ${ }^{47}$ In his inaugural address, for example, Giuliani pledged to place "much greater emphasis on stricter enforcement of the law to reverse the growing trend of ever increasing tolerance for lawless behavior." ${ }^{348}$ The institutions created in the 1970s, such as the MAC and the state's Financial Control Board,

44. See Smith, supra note 41; Michael J. Dear \& Jennifer R. Wolch, Landscapes of Despair: From Deinstitutionalization to Homelessness (1992).

45. For example, Giuliani declared a "fiscal emergency" in 1994, which helped legitimate further slashes to the municipal work force. Steven Lee Myers, Giuliani Outlines a Budget to Cut Government Size, N.Y. Times, Feb. 3, 1994, at Al, available at http://query.nytimes.com/gst/fullpage .html? res=990DE5D61339F930A35751C0A962958260.

46. Mayor Rudolph W. Giuliani, Inauguration Speech (Jan. 2, 1994) (transcript available at http://www.nyc.gov/html/records/rwg/html/96/inaug.html) [hereinafter Giuliani Speech].

47. See Bernard E. Harcourt, Illusion of Order: The False Promise of Broken Windows Policing (2001); Jeffrey Fagan \& Garth Davies, Street Stops and Broken Windows: Terry, Race, and Disorder in New York City, 28 Fordham URB. L. J. 457 (2000); Judith A. Greene, Zero Tolerance: A Case Study of Police Policies and Practices in New York City, 45 Crime \& Deline. 171, 171-74 (1999); Neil Smith, Giuliani Time: The Revanchist 1990s, 16:4 Soc. Text 1 (Winter 1998).

48. Giuliani Speech, supra note 46. 
were key players in legitimating these moves, and based their positive evaluations of Giuliani's strong-arm tactics on the views of the rating agencies. ${ }^{49}$

Many branches of municipal government that provided services for the poor were cut dramatically under Giuliani (see Table 1). For example, the share of the city budget allocated to the Department of Social Services declined from 23.8 percent in 1993 to 13.4 percent in 2001, a drop of 43.8 percent. ${ }^{50}$ In May 1998, for example, Giuliani announced that he was firing half of the staff in the Department of Homeless Services, with the long-term aim of closing the agency and privatizing remaining services. ${ }^{51}$ Although he did not entirely achieve this objective, the agency was significantly reduced during his tenure. ${ }^{52}$ Conversely, the proportion of the budget allocated to the Police Department increased from 5.7 percent to 7.8 percent of the city budget.

At the same time that Mayor Giuliani reduced spending on many social services for the poor, he encouraged the involvement of both non-profit and, even more controversially, for-profit institutions in city services. In particular, Giuliani sought to increase the involvement of profit-making firms in the provision of transportation facilities, city property management, residential care for the elderly and sick, prison health care, and homeless services. ${ }^{53}$ For example, whereas seven of New York City's homeless shelters were private in 1993, seventy-five of eightytwo shelters had been privatized by $2000 .^{54}$

49. See Sinclair, supra note 6, at 115. See also, James McKinley, Jr., Badillo Urges State to Study City Budget: Calls for Intervention and Then Softens Stand, N.Y. Times, June 2, 1993, at B1; James McKinley, Making Do With Less: City Budget Faces Need for Services, N.Y. Times, May 15, 1994, at A33 (showing how ratings agencies exert significant pressures on communities to make cuts in social spending and the workforce).

50. Giuliani also reduced expenditures for municipal hospitals (which serve the poor and uninsured) by $8.8 \%$ within the first six years. Lynne A. Weikart, The Giuliani Administration and the New Public Management in New York City, 36 URB. Aff. Rev. 359, 367-68 (2001).

51. Id. at 368-69.

52. Giuliani's policy responses to the homeless issues were generally constrained by the litigation efforts of the Coalition of the Homeless and other advocacy groups. In the course of this litigation, the Appellate Division of New York State Supreme Court ruled that under the state Constitution, all homeless people have a right to shelter. See Donna Wilson Kirchheimer, Sheltering the Homeless in New York City: Expansion in an Era of Government Contraction, 104 PoL. ScI. Q. 607 (1989).

53. Weikart, supra note 50.

54. Giuliani also attempted but failed to terminate the city's rent control laws, and sought but failed to sell three municipal hospitals to private companies. See id. at 375. 
Table 1. Change in New York City Budget Allocations, 1993-2001

\begin{tabular}{|l|l|l|l|l|l|}
\hline & $\begin{array}{l}1993 \text { Budget } \\
\text { Expenditures in } \\
\text { Dollars }\end{array}$ & $\begin{array}{l}1993 \\
\text { Proportion of } \\
\text { Budget }\end{array}$ & $\begin{array}{l}\text { 2001 Budget } \\
\text { Expenditures in } \\
\text { Dollars }\end{array}$ & $\begin{array}{l}2001 \\
\text { Proportion of } \\
\text { Budget }\end{array}$ & $\begin{array}{l}\text { Change in Propor- } \\
\text { tion of Budget } \\
1993-2001\end{array}$ \\
\hline $\begin{array}{l}\text { Department of } \\
\text { Social Services }\end{array}$ & $7,154,655,824$ & $23.8447 \%$ & $5,397,608,892$ & $13.4005 \%$ & $-43.8 \%$ \\
\hline $\begin{array}{l}\text { Public } \\
\text { Assistance }\end{array}$ & $309,299,725$ & $1.0308 \%$ & $279,947,592$ & $0.6950 \%$ & $-32.6 \%$ \\
\hline $\begin{array}{l}\text { Department of } \\
\text { Homeless } \\
\text { Services }\end{array}$ & $469,059,545$ & $1.5633 \%$ & $29,995,823$ & $0.0745 \%$ & $-95.2 \%$ \\
\hline City University & $533,546,517$ & $1.7782 \%$ & $435,842,870$ & $1.0821 \%$ & $-39.1 \%$ \\
\hline $\begin{array}{l}\text { Commission on } \\
\text { Human Rights }\end{array}$ & $10,485,477$ & $0.0349 \%$ & $6,924,110$ & $0.0172 \%$ & $-50.8 \%$ \\
\hline $\begin{array}{l}\text { Department of } \\
\text { Parks and } \\
\text { Recreation }\end{array}$ & $155,472,070$ & $0.5182 \%$ & $191,228,168$ & $0.4748 \%$ & $-8.4 \%$ \\
\hline $\begin{array}{l}\text { Police } \\
\text { Department }\end{array}$ & $1,705,089,082$ & $5.6826 \%$ & $3,166,293,842$ & $7.8608 \%$ & $+38.3 \%$ \\
\hline Total Budget & $30,005,203,638$ & $100 \%$ & $40,279,309,996$ & $100 \%$ & \\
\hline
\end{tabular}

Source: The City of New York Executive Budget Fiscal Year 1994 (David Dinkins, Mayor) and The City of New York Executive Budget Fiscal Year 2002 (Rudolph W. Giuliani, Mayor).

In addition to the loss of public funds for public resources and services, the increased importance of private capital in the management of these services and assets raises questions about democratic governance. New York City parks, for example, are public spaces that are no longer controlled by public agencies, but are increasingly managed by the private sector. ${ }^{55}$ Moreover, many private parks conservation and improvement efforts are spearheaded by Business Improvement Districts (BIDs), which are now flourishing across the United States. ${ }^{56}$ BIDs are areas that vote to assess themselves additional fees in order to provide supplementary services in that area. Although heralded by Mayor Giuliani as "one of the true success stories in the city" and "a tailor-made form of local government,",57 BIDs are in some tension with democratic principles. As Margaret Kohn argues,

55. See Sharon Zukin, The Culture Of Cities (1995).

56. Margaret Kohn, Brave New Neighborhoods: The Privatization Of Public Space (2004).

57. Zukin, supra note 55, at 34. 
First, the political influence in a Business Improvement District is usually directly proportional to the value of one's property, thereby violating the democratic principle of one-person, one-vote. Second, BIDs increase the impact of the already powerful business community on local government. Finally, BIDs, as private, nonprofit organizations, may be able to circumvent the constitutional provisions that require local governments to protect the civil liberties of their citizens..$^{58}$

In sum, while Giuliani was not able to achieve all of his fiscal policy objectives, he significantly reduced government expenditures on services for the poor and promoted privatization in several key areas, including public assistance, services for the homeless, parks and recreation, and higher education. These budgetary shifts adversely impacted poor people, increased the polarization of wealth in the city, and enhanced the role of private entities, particularly corporations. ${ }^{59}$ Giuliani himself often vindicated his actions with reference to the city's bond-ratings, indicating that positive ratings reflected market confidence in his cost-cutting practices. ${ }^{60}$

Urban ills such as homelessness, panhandling, drug use, petty crime, squatting, and illegal vending were targeted by Giuliani as security risks that should be dealt with quickly and harshly. These "risks" implicitly brought together physical fears of bodily injury (as a result of chaotic and lawless city streets) with fiscal fears of declining ratings and an unmarketable city (literally unsecuritized streets). The " $[\mathrm{k}]$ ey to attracting capital, tourists, and residents with disposable income is the promotion of the city as a safe place to live, work, travel, and shop."

\section{B. Zero Tolerance New York}

Giuliani's cuts in government expenditures on social services stand in sharp contrast to the enhanced budget and authority of the New York City Police Depart-

58. КонN, supra note 56, at 85.

59. For example, the number of people receiving public assistance declined by almost half under Giuliani, from 1,112,490 in 1993 to 518,823 in March 2001. In addition, food stamp participation decreased by 26\% between January 1996 and March 1999. See The Comm. on Soc. Welfare Law, The Ass'n of the Bar of the City of New York, Welfare Reform in New York City: The Measure of Success, http://www.nycbar.org/Publications/reports/show_html.php? rid = 41 (last visited Feb. 18, 2008).

60. Id.; see also Jonathan P. Hicks, Giuliani Tells Agencies to Use His Budget, Not the Council's, N.Y. Times, Nov. 29, 1994, at B3.

61. Alison Mountz \& Winifred Curran, Policing in Drag: Rudy Giuliani, Mexico City, and the Illusion of Control 6 (2007) (unpublished manuscript, on file with Alison Mountz). 
ment. Under Giuliani's leadership, the police department budget nearly doubled from $\$ 1.7$ billion in 1993 to $\$ 3.1$ billion in 2000 , a reflection of Giuliani's commitment to fighting crime and disorder through enhanced law enforcement. ${ }^{62}$

Giuliani's "zero tolerance" approach to crime and those he dubbed "disorderly" was based on "broken windows policing." ${ }^{33}$ Proponents of broken windows policing argue that neighborhoods that fail to fix broken windows or address other manifestations of "disorder" invite serious criminals into the neighborhood. ${ }^{64}$ Proponents of this theory also argue that many of those who committed minor offenses, like washing windows for tips, were in fact very dangerous individuals: "Squeegers were not merely a troubled population. They were capable of considerable mayhem." ${ }^{.55}$ Based on these assumptions, advocates of broken windows policing called for a fundamental reorientation of policing, one that offered city governments a broad and flexible means of regulating public spaces and removing those deemed "disorderly." In particular, the police were encouraged to consider misdemeanor offenses such as public drunkenness, prostitution, unlicensed vending, and panhandling as very serious matters. The NYPD was also encouraged to "stop and frisk" anyone deemed suspicious, a change that was, according to police officials, quite popular among uniformed officers. ${ }^{66}$

As a result of the implementation of this "tough" approach to crime and "disorder," the number of misdemeanor arrests increased about 80 percent, from approximately 129,403 in 1993 to 224,668 in $2000 .{ }^{67}$ Similarly, the number of drug arrests more than doubled, from 66,744 in 1993 to 140,122 in $2000 .^{68}$ Of these, a growing percentage involved only marijuana: New York City marijuana arrests rose from under 10,000 in 1993 to over 60,000 in $2000 .{ }^{69}$

The intensified enforcement of the laws prohibiting "quality of life" crimes had

62. See Greene, supra note 47 , at 173-74.

63. See James Q. Wilson \& George L. Kelling, Broken Windows: The Police and Neighborhood Safety, Atrantic Monthly, March 1982, at 29.

64. See George L. Kelling \& Catherine M. Coles, Fixing Broken Windows 19-22 (1996); Wesley G. Skogan, Disorder and Decline: Crime and the Spiral of Decay in American Neighborhoods 36-50 (1992); Wilson \& Kelling, supra note 63, at 29.

65. Kelling \& Coles, supra note 64, at 142.

66. See William J. Bratton \& Peter Knobler, Turnaround: How America's Top Cop Reversed the Crime Epidemic (1998).

67. Greene, supra note 47, at 184. See also, New York State Division of Criminal Justice Services, Adult Arrests, http://criminaljustice.state.ny.us/crimnet/ojsa/arrests/years.htm (last visited June 12, 2008).

68. Greene, supra note 47 , at 184 .

69. Andrew Golub et al., The Race/Ethnicity Disparity in Misdemeanor Marijuana Arrests in New York City, 6 Criminology \& Pub. Pol'y 131, 139-45 (2007). 
a pronounced impact on the city's homeless population, as many were arrested in the new effort to crack down on "disorder." ${ }^{\text {"70 }}$ In some cases, it seemed that the police went out of their way to harass the homeless. For example, undercover police offcers began riding the M35 bus to arrest those on their way to shelters who did not pay the $\$ 2$ fare. In 1999, Police Commissioner Howard Saffir announced that homeless people sleeping outside would be summonsed or arrested for disorderly conduct. In response to public outcry, Giuliani argued that "[the right to sleep in the streets] doesn't exist anywhere. The founding fathers never put that in the Constitution."'? At the same time, Giuliani tried to change city rules to require that homeless people who did not comply with welfare-to-work requirements, treatment protocols, and other rules be barred from the entire city shelter system for at least thirty days. ${ }^{27}$

Also under Giuliani's leadership, street vendors-an overwhelmingly immigrant and poor population-were subjected to enhanced regulation, sanctions, and seizure of assets. In his first year as mayor, arrests for illegal vending increased by 38 percent; summonses for illegal vending increased by 40 percent; and seizures of vendors' property increased by 37 percent. ${ }^{73}$ In 1996, at the urging of BIDs, Giuliani created the Street Vendor Review Panel which also sought to restrict the spaces in which street vendors could operate. In 1998, Giuliani successfully advocated for a law that banned street vendors from 144 of the most favorable blocks and intersections. ${ }^{74}$

In short, Giuliani sought to create order and enhance the quality of urban life by downsizing government, particularly government agencies that served the poor, promoting privatization, and intensifying law enforcement efforts and authority. A number of new "sticks" were introduced to ensure compliance with Giuliani's vision of an orderly and secure city, and the vast majority of these tactics were wielded against the city's most vulnerable residents. The practices and policies enacted in New York City have been vigorously promoted by Giuliani Partners and other

70. See Harcourt, supra note 47, at 165-66; Heather Barr, Policing Madness: People with Mental Illness and the NYPD, in Zero Tolerance: Quality of Life and the New Police Brutality in New York City 50, 53 (Andrea McArdle \& Tanya Erzen eds., 2001); Peter A. Barta, Giuliani, Broken Windows and the Right to Beg, 6 Geo. J. on Poverty L. \& PoL'y 165, 168-69 (1999); Elisabeth Bumiller, In Wake of Attack, Giuliani Cracks Down on Homeless, N.Y. Times, Nov. 20, 1999, at A1.

71. Bumiller, supra note 70 , at $\mathrm{Al}$.

72. See Barr, supra note 70, at 62.

73. Rudolph W. Giuliani \& William J. Bratton, Police Strategy No. 5: Reclaiming the Public Spaces of New York, OfFice of THE MAYOR, 1994 (data derived from author's research notes of archival material available at the New York City Municipal Archive); see also Mitchell Duneier, Sidewalk 231-52 (1999) (discussing the regulation of street vendors).

74. See Smith, supra note 47 , at 14. 
transnational global security consulting firms, as well as by U.S.-based bond-rating agencies. In what follows, we consider the exportation of this type of fiscal disciplining and rationality through bond-ratings judgments and global security partnerships operating in Mexico and Mexico City in particular.

\section{Exporting Neoliberalism}

\section{A. Disciplining Mexico}

The rise of global finance systems have resulted in new kinds of controls over the scoring and movement of credit worldwide. ${ }^{75}$ These agents and institutions of credit are implicated in shifting forms of governance, with previously centralized systems of authority now relocated in multiple directions and in many new forms of public-private partnerships. ${ }^{76} \mathrm{With}$ respect to metropolitan governance, especially in developing countries, the globalization of finance, and in particular the influence of credit ratings by international corporations such as Moody's and S\&P, has had a significant impact on urban autonomy and policy. ${ }^{77}$ The agencies have influence over a capital market environment fearful of risk, and they often determine-through the allocation of credit-the development options of an entire city or nation. ${ }^{78}$

Mayors, bureaucrats, and local politicians are all deeply aware of the implications of credit ratings for their personal careers and for their constituencies, and thus adapt to and adopt the social and economic adjustments demanded by these U.S.-based agencies. Giselle Datz writes, "[A] serious implication of rating agencies' influence on international capital markets today is not only to be found in their influencing of private investors, but in their influencing of developing countries' governments, which tie policy making to the quasi veto power of ratings."

Thus the power of ratings in developing economies comes from their entry into

75. See Tony Porter, Globalization and Finance (2005).

76. See Martin Hewson \& Timothy J. Sinclair, The Emergence of Global Governance Theory, in Approaches to Global Governance Theory 3, 7 (1999); Randall D. Germain, The International Organization of Credit: States and Global Finance in the World Economy (1997).

77. See Sinclair, supra note 6, at 1-2; Наск worth, supra note 11, at 23-29.

78. Attracting private sector capital investment has become increasingly vital for almost all development sectors in emerging economies. Over the past two decades, private sector investment in developing countries rose from $\$ 45$ billion to $\$ 300$ billion. By contrast, official sector capital investment rose only from $\$ 30$ billion to $\$ 80$ billion over the same time period. See Lynn Selhat, How Private Financiers See Development: High Risk, High Return, OECD Observer, Oct. 2000, at 45.

79. Giselle Datz, Reframing the Development and Accountability: The Influence of Sovereign Credit Ratings on Policy Making in Developing Countries, 25 ThIRD WorLd Q. 303, 304 (2004). 
the calculations of policy makers of every political hue and at every scale of governance. Further, the highly subjective notion of risk encourages submission to "expert" knowledge, which is often required by insurance companies and other financial entities and in turn impacts the behavior and thinking of urban politicians. In the case of S\&P, Moody's Investor Services, and Fitch, this expert knowledge is predicated on a firm belief in the efficacy and necessity of U.S.-style neoliberal market reforms. For example, after Vicente Fox Quesada was elected President of Mexico in 2000, S\&P indicated a positive outlook for a ratings upgrade (to investment grade) if the administration followed certain guidelines such as ending deficit spending, strengthening the banking system, and reducing state control of key economic sectors, particularly energy. "It really is a question of how effective we think the Fox administration is going to be in implementing the structural reform agenda," said John B. Chambers, deputy head of the sovereign ratings group at $S \& P^{80}$

In Mexican cities and financial circles, the impact of credit ratings agencies has been strongly felt since the deepening integration with the U.S. economy, symbolized most concretely by the creation of the North American Free Trade Agreement (NAFTA) in $1993 .{ }^{81}$ In that same year, S\&P acquired CAVAL, a Mexican credit ratings agency, and subsequently offered bullish assessments of Mexico's economic prospects just prior to the national elections and the devaluation of the peso and financial crisis of 1994-95. ${ }^{82}$ This (mistakenly) positive assessment coincided with a strong marketing push by S\&P in Mexico. Six years later, Moody's projected similar bullish assessments for Mexico, raising the country's ratings from junk to investment grade status, also just prior to a presidential election. ${ }^{83}$ With this move, Moody's virtually guaranteed a wealth of post-election contracts, but also raised the thorny question of a conflict of interest. "Moody's announcement was widely praised by the Mexican government and sparked a rally in local bond and equity markets, bolstering Moody's chances of winning mandates for a long queue of government entities and corporations planning to issue bonds in the ensuing months."'s4

80. Anthony De Palma, Mexico Victor Faces Choices on Economy, N.Y. Trmes, July 7, 2000, at C1. See also John Authers, Mexico Sees S\&P Ratings Upgrade, Fin. Times, Feb. 8, 2002, at 27; John Authers and Sara Silver, Debt Rating Upgrade Gives Boost to Mexico, Fin. Times, Feb. 8, 2002, at 6.

81. See Credit Ratings, with their Awesome Power, Come to Mexico, Institutional Investor, Jan. 1994, at 112-13.

82. Roy C. Smith \& Ingo Walter, Rating Agencies: Is there an Agency Issue? 41 (Stern School of Business, New York University Working Paper, Feb. 18, $2001 \mathrm{draft}$ ) available at http://wwwl .worldbank.org/finance/assets/images/Rating_Agencies.pdf.

83. See Graham Field, Going Separate Ways, Latin Fin., Feb. 2001, at 18-19.

84. Smith \& Walter, supra note 82 , at 41 . 
The articulation of corporate profit-making by the ratings agencies with policy directives advocating neoliberal reforms such as privatization, austerity, and integration with the U.S. economy, indicates a few of the challenges to urban autonomy that confront politicians in developing countries. Ratings directives permeate all scales of governance and are linked with the political fortunes of parties and individual actors. As with the financial crisis in New York City in the 1970s, the "fiscal discipline" advocated and monitored by the credit agencies is increasingly imposed on developing cities and regions from above, in this case from both national and international institutions and directives. ${ }^{85}$

This has been the case for Mexico City, a stronghold of the leftist PRD (Democratic Revolution Party) party since the mid 1990s. The center-right PRI (Institutional Revolutionary Party) and rightist PAN (National Action Party) parties at the national scale have largely dictated many of the spending priorities for the city, as well as encouraging the never-ending "war on drugs," which has led to the targeting of poor areas, harassment of the population in these neighborhoods and, frequently, their subsequent gentrification. ${ }^{86}$ These practices and policies are often rationalized and legitimated with reference to the priorities of global institutions, including the International Monetary Fund (IMF) and World Bank, as well as private investors and the financial instruments they rely on to delineate risk, such as S\&P, Moody's, and Fitch. ${ }^{87}$

Lopez Obrador, who served as mayor of Mexico City before running for President in 2006, instituted large public works projects and a number of social programs in the city, including a government pension program for the elderly. ${ }^{88}$ When it appeared that he might win the presidential election, worry about future undisciplined government spending caused havoc in the bond market. ${ }^{89}$ This concern was alleviated somewhat by Obrador's "Cambridge-educated" economic adviser, Rogelio Ramirez

85. See Saskia Sassen, Losing Control: Sovereignty in the Age of Globalization 16 (1996).

86. See Sam Enriquez \& Carlos Martinez, Mexico City 'Narco-neighborhood' is Targeted, L.A. Times, Nov. 14, 2006, at A4; Mexico Politics: Crime Watch, Economist Intelligence Unit, Nov. 2, 2006.

87. The link between drug-related violence and threats to foreign investment is made repeatedly in speeches by national figures such as Calderon. See Hector Tobar \& Cecilia Sanchez, Toll Mounts in Mexico's Drug War, L.A. Times, Nov. 14, 2006, at A4; see also Mexico Politics: Law and No Order, Economist Intelligence Unit, Oct. 9, 2006, at 3 (suggesting that the most significant impact on foreign direct investment is yet to come).

88. E. Eduardo Castillo, Mexico's Leftist Candidate Walks Fine Line Between Free-Market, Socialist Policies, Associated Press, May 7, 2006.

89. See Adriana Arai, Worry About Candidate Hurts Bonds in Mexico, Int'l Herald Trib., June 26, 2006, at 15 ("Bonds from Mexico's biggest corporate borrowers have fallen more than debt of other Latin American companies on concern that a presidential candidate who has promised to increase spending to fight poverty could win the national election Sunday."). 
de la $\mathrm{O}$, who assured the private sector that Obrador would not bring a new economic model to Mexico. ${ }^{90}$ Moody's Latin America analyst, Alfredo Coutino, also tamed concerns about financial risk related to an Obrador victory: "The markets outside of Mexico, especially in the United States, see that Lopez Obrador's proposal isn't that bad and that he doesn't represent a risk to the free-market model. ${ }^{.91}$ Nevertheless, at least one company located in Mexico City, America Movil, had its bonds decline by 9.7 percent at this time, partially as a result of political fears. "Why do I want a small yield pickup on America Movil when I can just hold a high-quality corporate for the same amount, without the political risk?' asked Teresa Kong, a senior portfolio manager for Barclays Global Investors, in an interview from San Francisco. ${ }^{\text {,92 }}$

Leftist mayors like Obrador and his successor, Marcelo Ebrard, find themselves caught between their political promises of local spending for needed social services and the all-important movement of bond values and ratings operating on a transnational scale. Their desperate desire to maintain strong relations with U.S.-dominated agencies frequently leads to municipal policies at odds with their stated mandates of poverty alleviation, including new "security measures" intended to drive drug smugglers and sidewalk merchants out of particular neighborhoods. For example, in Tepito, a poor neighborhood in the center of Mexico City that was the target of a police "drug-busting" raid in February 2007, evicted residents told reporters they felt "betrayed," and hung an effigy of Ebrard in protest. ${ }^{93}$

For many mayors such as Ebrard, the increasingly global rhetoric of law and order and zero tolerance relating to physical security, has become intrinsically linked with financial security. This is particularly evident in the tourist industry and particularly in historic centers of cities such as Mexico City. The war on drugs often takes place in neighborhoods like Tepito which are near tourist-oriented urban spaces; the harassment and/or eviction of the residents of these spaces makes the streets safer for visitors and also opens up these neighborhoods to financial speculation and gentrification. ${ }^{94}$

How have mayors like Ebrard learned about law and order policing, and who is

90. Castillo, supra note 88.

91. Leftist's Vacillations Hampering Him in Mexican Elections, Assocıated Press, May 15, 2006.

92. Arai, supra note 89 , at 15.

93. Enriquez \& Martinez, supra note 86 , at A9.

94. See Claudia Boyd-Barrett, Authorities Announce Yet Another New Unit of Specialized Police, Emerging Markets Datafile, Dec. 17, 2002 ("For the benefit of those just stopping over in Mexico City, new multi-lingual Tourist Police keep a watchful eye over the capital's much-visited Historic Center. With a similar mandate, horse-backed 'Traditional Police' in mariachi hats and embroidered jackets patrol the famous Alameda park a few blocks away from the central square, combining tourist entertainment with crime-fighting."). 
profiting from the rise of this new form of securitization of cities? We address these questions through an examination of the transnational exportation of zero tolerance rhetoric from New York City and the rise of global security partnerships worldwide.

\section{B. The Export of Zero Tolerance}

Advocates and opponents of zero tolerance policing agree on at least one thing: the New York approach to crime is often portrayed as a model for cities across the United States and around the globe. ${ }^{95}$ Although many academic critics argue that Giuliani's crime policies had little to do with the crime drop in New York City, Giuliani routinely takes, and is given, credit for making New York City safe again. "Giuliani has become the international face of zero tolerance policing, having been credited with making New York the safest big city in America through his crackdown on "squeegee men," noise, pedestrians and street vendors." 96

Within the United States, the gospel has been spread primarily by former NYPD Commissioner William Bratton (now Chief of Police in Los Angeles), Mayor Giuliani, the Manhattan Institute, and the mass media, which routinely attributes the crime drop in New York to changes in NYPD practices. Many European political leaders, as well as officials from Australia, New Zealand, and South Africa, have visited NYPD headquarters and incorporated much of the rhetoric, if not the practice, of zero tolerance in their home countries.

Zero tolerance policing has had a notable impact on debates over policing in Latin America as a result of ongoing efforts by consulting organizations to promote the "New York model." Mexico City illustrates how politicians may be induced to look to NYC for a solution to their problems for many reasons, including: popular concern about crime and violence, city officials' desire to maintain positive credit ratings and attract foreign investment, and business leaders' willingness to fund against crime. ${ }^{98}$

95. See, e.g., Christian Parenti, The Revolution in American Policing: The Science of Kicking Ass, Z Mag., Dec. 1997; Charles Sahm, New York Revitalizes U.S. Policing, City J., Winter 2005, at 18; Loic Wacquant, The 'Scholarly Myths' of the New Law and Order Doxa, in Socialist Register 2006: Telling the Truth 93, 99 (Leo Panitch \& Colin Leys eds., 2005).

96. Mountz \& Curran, supra note 61 , at 10.

97. See Loic Wacquant, Toward a Dictatorship over the Poor? Notes on the Penalization of Poverty in Brazil, 5 Punishment \& Soc'y 197, 198 (2003).

98. See Jens Erik Gould, High Crime Stifles Latin Economies, N.Y. Times, Oct. 17, 2006, at C1. 


\section{Giuliani Partners in Mexico City}

After being declared America's "top cop" by Time Magazine in 1996, New York Police Chief Bratton stepped down from public office and formed his own private consulting company, The Bratton Group, L.L.C. The consulting group has worked on four continents, offering consulting services that promote, among other things, zero tolerance policing. At a time when neoliberal institutions such as the World Bank and bond-rating agencies, as well as foreign investors themselves, express heightened concern about crime and insecurity, municipal leaders feel compelled to take action-any action-in South America, where he has advised officials on both crime policy and running on an anti-crime platform. ${ }^{99}$ Similarly, upon retiring from the mayor's office, Rudy Giuliani formed Giuliani Partners, a consulting organization staffed by many of his top aides from City Hall and former police commissioner Bernard Kerik. ${ }^{100}$

In 2002, Giuliani Partners signed a $\$ 4.3$ million contract to advise Mexico City officials in their efforts to reduce crime. Notably, however, Giuliani did not contract with the city, but with the man who put up the funds for the lucrative contract, Carlos Slim Heru, the wealthiest man in Latin America. ${ }^{101}$ As one journalist put it, "The formula is largely the same, except that this time Giuliani wasn't elected. He was not hired by any public agency or official." 102 More surprising was the fact that the consulting arrangement had the blessing of the leftist Mayor Lopez Obrador, who was reportedly concerned about the negative impact of the crime problem on plans to revitalize parts of the city, as well as widespread popular frustration about crime, violence, and police corruption. ${ }^{103}$

The contract was announced with much fanfare and media hype. A year after signing the contract, and after several delays, Giuliani’s firm presented 146 recommendations to the municipality. These recommendations were wide-rang-

99. In 2000, Kroll Associates, a leader in the private security consulting industry, announced that it has signed an agreement with The Bratton Group L.L.C. "to provide public safety-focused administration, training and operational re-engineering and analysis consulting services to Kroll's clients worldwide." Press Release, Kroll Associates, Kroll Associates Announces Signing of Agreement with Former New York City Police Commissioner William J. Bratton and the Bratton Group LLC (Nov. 2, 2000), available at http://www.prnewswire.co.uk $/ \mathrm{cgi} / \mathrm{news} / \mathrm{release}$ ?id $=12346$.

100. Mountz \& Curran, supra note 61 , at 16.

101. Id. at 13.

102. Noah Friedsky, Giuliani's Mexico City Game: A Story of Fear, Power, and Money, Narco News Bull., Sept. 11, 2003, at 1.

103. See Jordi Pius Llopart, Robocop in Mexico City, NACLA Rep. on the Am., Sept.-Oct. 2003, at 22 . 
ing, and included the recommendation to develop and use Compstat, ${ }^{104}$ install cameras and lighting, enhance police training, use breathalyzers to enforce laws against drunk driving, and target illegal street vendors and windshield washers. ${ }^{105}$ The recommendations, particularly those involving the criminalization of street vendors, were controversial from the start. A leading Mexican criminologist, Rafael Ruiz-Harrell, announced that "[z]ero tolerance is a useless concept in Mexico."106 Many commentators worried that Giuliani's zeal to "clean up" the streets would essentially criminalize the many people who participate in Mexico City's informal economy. Whereas New York officials estimated that about two hundred people were working as "squeegee guys" in New York City when the crackdown on window washing began in that city, an estimated twenty thousand people-mostly street children-survived by washing windows in Mexico City. ${ }^{107}$

Critics also worried that the rhetoric associated with zero tolerance would exacerbate the already severe problem of police violence, and pointed out that many of the recommendations could not be implemented without modifying the Mexican Constitution. ${ }^{108}$ Still others objected to the idea of relying on the police to solve economic problems:

Perhaps the greatest disadvantage of the [Giuliani] approach is the pressure it places on the police to solve problems that are largely beyond its competence to resolve . . Mexico City's hundreds of thousands of franeleros, windshield wipers and ambulatory vendors are a reflection of a massive informal sector that has no real counterpart in New York ... [t]heir significant presence is virtually guaranteed by the weaknesses and inequities in the District's economy and local public administration. ${ }^{109}$

The long-term impact of Mexico City's consultation with Giuliani Partners

104. Compstat stands for "Computer Statistics," and allows for spatial analysis of criminal events in order to identify "hot spots." See generally Andrew Karmen, New York Murder Mystery: The True Story Behind the Crime Crash of the iggos (2000).

105. See Daniela Gerson, In Mexico City, Few Cheers for Giuliani, The N.Y. Sun, Apr. 11, 2005 at 1. 106. Letta Tayler, Giuliani's Crime Plan a Work in Progress, Seattre Times, Aug. 11, 2004, at A10.

107. See Amy Guthrie, When Cops are Thugs: Zero Tolerance Comes to Mexico City, Village Voice, Aug. 27-Sep. 2, 2003, at 44; Friedsky, supra note 102.

108. See Guthrie, supra note 107 , at 45.

109. Letter from Lawyers' Committee for Human Rights, Letter to Marcelo Ebrard Casaubon, Secretary of Public Security for the Federal District, Mexico City (Sept. 4, 2003), available at http://www.humanrightsfirst.org/mexico_policing/ltr_Giuliani_recomm_090403.pdf. 
on crime policy is unclear. On the one hand, many of Giuliani Partners' recommendations appear to have been largely ignored. Window washers and mobile street vendors, for example, continue to work in the streets without substantial risk of arrest. On the other hand, some of its recommendations were implemented: the police placed "panic buttons" on city buses and installed surveillance cameras in high crime areas. Bail was also increased for many offenders, thus exacerbating the problem of jail overcrowding. Even before the release of the report, the Mexico City Legislative Assembly, inspired by the spirit of zero tolerance, toughened penalties for a number of minor offenses and mandated that those who commit petty theft (including snacking on store food while shopping) receive at least six months in jail. ${ }^{110}$ This new "Law of Civic Culture" also increased the penalties for other common violations-including leaving dog excrement on the street, dumping furniture, asking for a tip for "fire-eating" (common among street children), and prostitution. After a long dispute regarding the constitutionality of its provisions, the law was very recently upheld by the Supreme Court of Mexico, a ruling that clears the way for other municipalities to adopt similar legislation. ${ }^{11}$

This expanded definition of crime provides the police with yet another method for extortion, and leaves open the possibility that these laws will be enforced under particular circumstances or locales..$^{112}$ Indeed, it appears that the main legacy of Giuliani's work has been felt in Mexico City's historic district, now the site of major "urban renewal" (i.e., gentrification) efforts. Interviews with expert and non-expert residents of Mexico City revealed a widespread perception that Giuliani's policies were implemented only "in the tourist zones." Notably, the billionaire who fronted the cash for Giuliani's contract, had previously acquired many properties in these areas, properties he was busily converting to loft apartments. ${ }^{13}$

In the end, Giuliani Partners was paid less than its widely reported $\$ 4.3$ million fee, and its contract was not renewed. Mexico City's new police chief, Joel Ortega, announced in 2005 that he is "no fan of Giuliani." 114 The plan did little to improve the quality of life for the millions of Mexico City's poor residents, and may have rendered their lives more difficult by enhancing police power without addressing poverty or police corruption. Under the new leadership of former po-

110. See Guthrie, supra note 107 , at 45.

111. Interview with Mario Arroyo Juarez, Director, Sistemas de Información para la Seguridad Humana, SC. (March 29, 2007) [herinafter Juarez Interview].

112. See Jo Tuckman, Zero Tolerance? My Money's on the Traffic Light Fire-Eaters, Guardian, Oct. 23, 2004, at 21.

113. Mountz \& Curran, supra note 61, at 14.

114. Gerson, supra note 105. 
lice chief turned Mayor Marcelo Ebrard, city officials now seek inspiration from cities that have adopted less punitive crime-fighting techniques, including Palermo, Italy and Bogotá, Columbia. ${ }^{15}$ While the impact of Giuliani Partners in Mexico City has been less drastic than Giuliani's detractors feared, this has largely been the result of political opposition to the plan. It remains quite possible that the export of zero tolerance to other Latin American cities could have much more long-lasting and negative repercussions. Indeed, after completing his report to Carlos Slim Heru, Giuliani Partners has engaged in "partnerships" in countries throughout Latin America, Europe, and the African subcontinent.

\section{Conclusion}

In this article we show how two key transnational private institutions-bondrating agencies and the crime consulting industry-increasingly influence urban space and policy. Although transnational in orientation, each was born in the United States and continues to promote U.S. interests and priorities. Private, undemocratic, and lacking accountability, these institutions now have a significant impact on the governance of municipalities around the globe. Working together, bond-rating agencies and crime consulting organizations encourage fiscal and social discipline and a general enhancement of the state's coercive power over those who are poor, homeless, and consigned to the informal sector. These institutions also encourage a weakening of democratic rights-rights to political participation, representation, and public accountability - as well as a deterioration of human rights to food, housing, dignity, and general welfare protection by the state.

The negative results of Giuliani Partners' work in Mexico City underscores the importance and viability of political resistance to global neoliberalism and its institutional handmaidens. Although powerful, the impact of these institutions will ultimately be determined in the course of political struggle.

115. Juarez Interview, supra note 111. 


\section{The Global South}

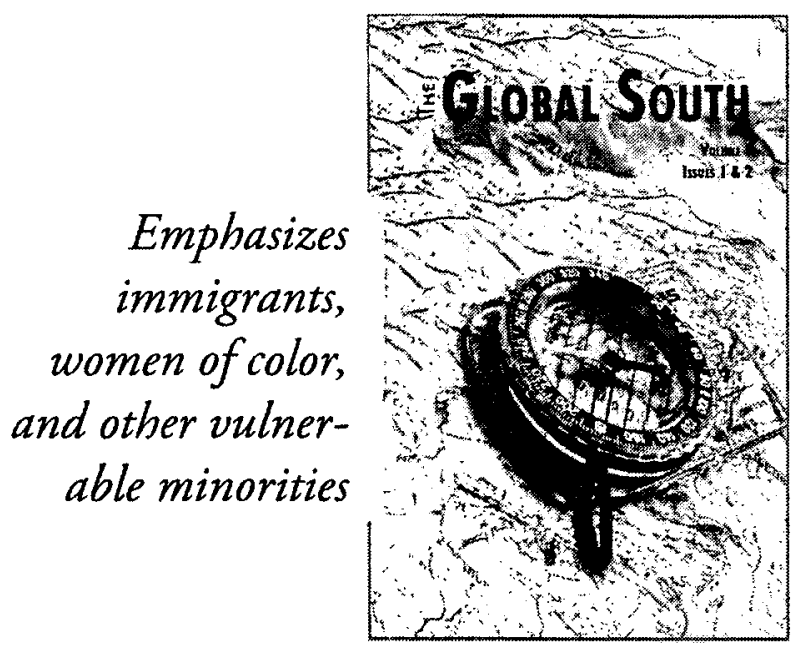

Edited by Alfred J. López and Adetayo Alabi

p-ISSN 1932-8648 e-ISSN 1932-8656

The Clobal South concentrates on the literatures and cultures of those parts of the world that have experienced the most political, social, and economic upheaval and have suffered the brunt of the greatest challenges facing the world under globalization: poverty, displacement and diaspora, environmental degradation, human and civil rights abuses, war, hunger, and disease. In keeping with this focus, TCS features original contributions focusing on oppositional subaltern cultures. Immigrants, women of color, and other vulnerable minorities are emphasized.

Institutions:

print $\$ 65.00$

electronic $\$ 58.50$

print \& electronic $\$ 91.00$
Individuals:

print $\$ 35.00$

electronic $\$ 31.50$

print \& electronic $\$ 38.50$

Please note, print subscriptions will be fulfilled after the second issue of each volume is published electronically.

Now available

on... 